\title{
RECORDS OF ODONTOCETES IN THE NORTHERN INDIAN OCEAN (1981-1982) AND OFF THE COAST OF SRI LANKA (1982-1984)
}

\begin{abstract}
Abigail Alling ${ }^{2}$
(With six text-figures)

Surveys for cetaceans were conducted from a $9 \mathrm{~m}$ sloop, s/rv Tulip (29 November 1981-12 February 1982) in the northwest Indian Ocean and off the coast of Sri Lanka (13 February-17 March 1982, 20 January-24 April 1983, and 22 February-25 May 1984). Although the principal purpose was to locate and track sperm whales, Physeter macrocephalus, observations of other cetaceans were recorded. Odontocetes were observed during the three years in the following relative frequencies (number of observations/number of individuals): spinner dolphin, Stenella longirostris $(48 / 1,804)$, striped dolphin, Stenella coeruleoalba (12/531), spotted dolphin, Stenella cf. Stenella attenuata (14/656), common dolphin, Delphinus delphis (14/711), Risso's dolphin, Grampus griseus (37/321), bottlenose dolphins, Tursiops sp. (39/477), humpback dolphin, Sousa sp. (4/10), false killer whale, Pseudorca crassidens (6/43), Fraser's dolphin, Lagenodelphis hosei (1/12), pygmy killer whale, Feresa attenuata (5/10), Cuvier's beaked whale Ziphius cavirostris (1/2), Pilot whale, Globicephala cf. Globicephala macrorhynchus (3/78), Southern bottlenose whale, Hyperoodon planifrons $(2 / 42)$, and unidentified dolphins $(85 / 664)$. Behavioural observations and habitat preferences are discussed.
\end{abstract}

\section{N T R O D U C T I O N}

In 1979 members of the International Whaling Commission (IWC) voted to declare the northern portion of the Indian Ocean $\left(20^{\circ}\right.$ $\mathrm{E}-130^{\circ} \mathrm{E}$ longitude, above $55^{\circ} \mathrm{S}$ latitude) a marine mammal sanctuary. This international commitment was accompanied with an urgent request that "benign research" of the living whales in the sanctuary be commenced. In response to this request, the World Wildlife FundNetherlands (WWF) raised funds for a three year (1982-84) study of sperm whales to be carried out from a $9 \mathrm{~m}$ research vessel, $\mathrm{s} / \mathrm{rv}$

1 Accepted October 1984.

2 School of Forestry and Environmental Studies, 205 Prospect Street, New Haven, CT 06511, U.S.A.
Tulip. By agreement with the IWC, the study was also designed to obtain information about the identity, distribution, and relative abundance of all cetaceans sighted. This paper reports on the observations of free ranging odontocetes, other than sperm whales, in the northern portion of the sanctuary from November 1981 through 25 May 1984.

\section{Materials AND Methods}

On 29 November 1981, s/rv Tulip sailed from the Suez Canal to begin a survey of cetaceans in the Red Sea and northern Indian Ocean. The vessel arrived in Sri Lanka on 14 February 1982 after stops in Djibouti, Oman, and India (Fig. 1). From 14 February to 17 March 1982, s/rv Tulip was used to follow 


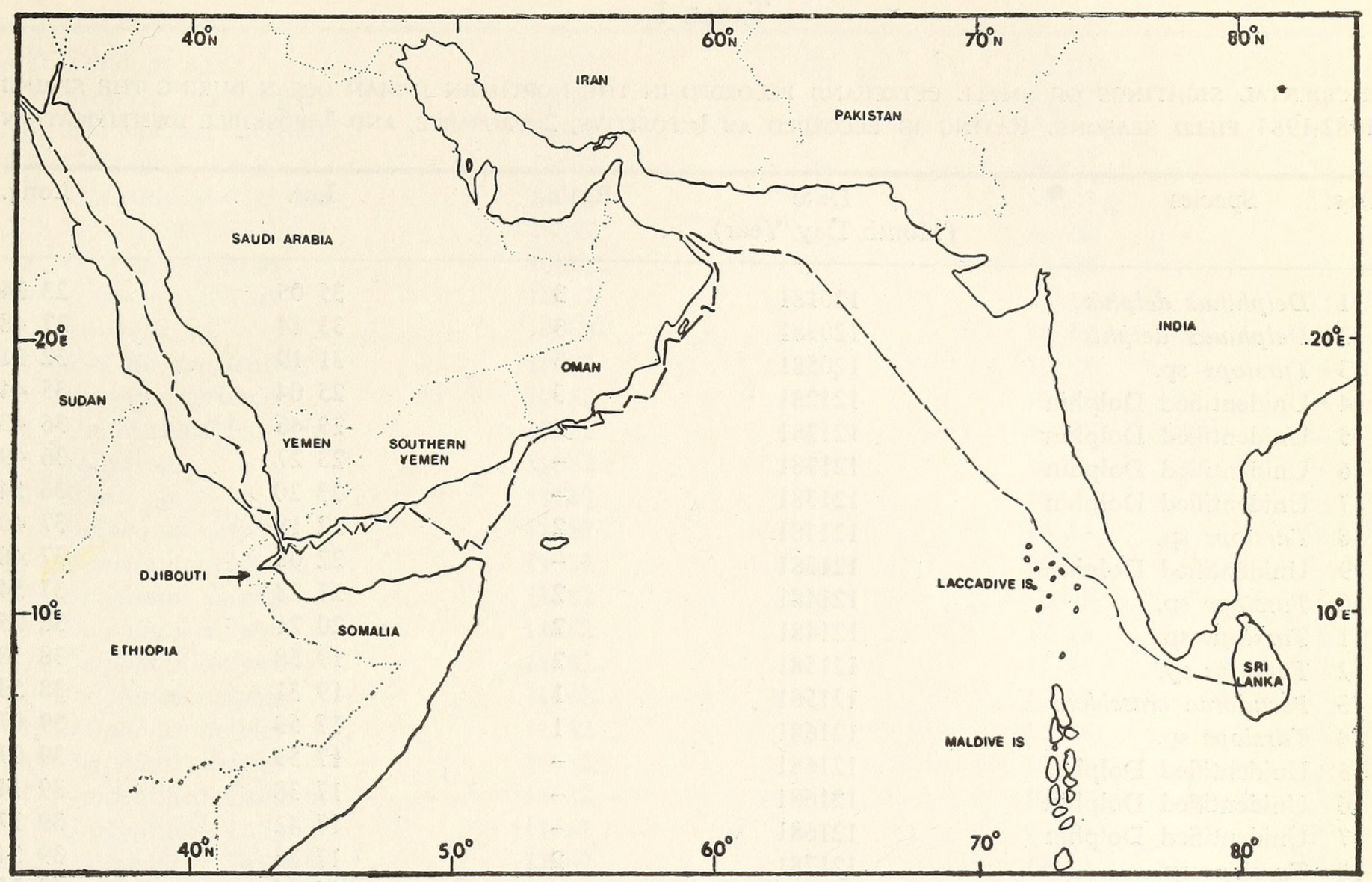

Fig. 1. The route sailed by sr/v Tulip 29 November, 1981 through 12 February, 1982.

sperm whales off the west coast of Sri Lanka. During the following two field seasons (20 January-24 April 1983 and 22 February-25 April 1984) the vessel was based at Trincomalee, a harbor on the northeast coast of Sri Lanka, and used to study cetaceans within approximately $100 \mathrm{~nm}$ of that port. The research was on sperm, Physeter macrocephalus and blue, Balaenoptera musculus sp., whales. However, during all field seasons the crew recorded information on all cetaceans sighted.

A constant watch was kept during daylight hours. At least one of five crew members was positioned in the stern of the boat, approximately $3 \mathrm{~m}$ above sea level for a maximum three hour watch. When cetaceans were seen the vessel's course was altered to determine species and numbers, but the engine was only used when the speed of the vessel dropped below two knots. Oceanographic variables (e.g. surface water temperature, wind speed, wind direction, etc.) were measured and recorded for each sighting to examine such effects on cetacean distribution and abundance. Surface water temperature was recorded in degrees celsius and depth was monitored up to 1,100 $\mathrm{m}$, the operational limits of the Simrad Skipper 603 depth sounder. Local time, date, and position were obtained from a Tracor Transtar Satellite Navigator.

For this research, a "herd" was defined as a group of cetaceans seen moving in the same direction and at similar speeds. A "sighting" was considered to be an event which began when the first individual became visible and ended when the last was no longer visible. 


\section{TABLE 1}

INCIDENTAL SIGHTINGS OF SMALL CETACEANS RECORDED IN THE NORTHERN INDIAN OCEAN DURING THE SPRING 1982-1984 FIELD SEASONS. RATING IS RECORDED AS 1=POSITIVE, 2=PROBABLE, AND 3=POSSIBLE IDENTIFICATION

\begin{tabular}{|c|c|c|c|c|c|}
\hline Obs. & Species & $\begin{array}{c}\text { Date } \\
\text { (Month/Day/Year) }\end{array}$ & Rating & Lat. & Long. \\
\hline 1 & Delphinus delphis & 120181 & 3 & 3505 & 2324 \\
\hline 2 & Delphinus delphis & 120381 & 3 & 3314 & 2748 \\
\hline 3 & Tursiops sp. & 120581 & 3 & 3119 & 3221 \\
\hline 4 & Unidentified Dolphin & 121281 & 3 & 2504 & 3544 \\
\hline 5 & Unidentified Dolphin & 121281 & 3 & 2346 & 3643 \\
\hline 6 & Unidentified Dolphin & 121281 & - & 2327 & 3649 \\
\hline 7 & Unidentified Dolphin & 121381 & - & 2320 & 3654 \\
\hline 8 & Tursiops sp. & 121381 & 2 & 2218 & 3740 \\
\hline 9 & Unidentified Dolphin & 121381 & - & 2208 & 3748 \\
\hline 10 & Tursiops sp. & 121481 & 2 & 2128 & 3754 \\
\hline 11 & Tursiops sp. & 121481 & 2 & 2021 & 3825 \\
\hline 12 & Tursiops sp. & 121581 & 2 & 1958 & 3838 \\
\hline 13 & Pseudorca crassidens & 121581 & 1 & 1931 & 3853 \\
\hline 14 & Tursiops sp. & 121681 & 1 & 1753 & 3907 \\
\hline 15 & Unidentified Dolphin & 121681 & - & 1753 & 3907 \\
\hline 16 & Unidentified Dolphin & 121681 & - & 1738 & 3914 \\
\hline 17 & Unidentified Dolphin & 121681 & - & 1742 & 3917 \\
\hline 18 & Tursiops sp. & 121781 & 2 & 1723 & 3954 \\
\hline 19 & Tursiops sp. & 121781 & 3 & 1644 & 4025 \\
\hline 20 & Unidentified Dolphin & 121781 & - & 1643 & 4028 \\
\hline 21 & Tursiops sp. & 121881 & 2 & 1620 & 4104 \\
\hline 22 & Tursiops sp. & 121881 & 2 & 1606 & 4145 \\
\hline 23 & Sousa sp. & 122281 & 3 & 1309 & 4314 \\
\hline 24 & Tursiops sp. & 122381 & 3 & 1212 & 4327 \\
\hline 25 & Delphinus delphis & 122381 & 3 & 1205 & 4325 \\
\hline 26 & Delphinus delphis & 122381 & 3 & 1201 & 4327 \\
\hline 27 & Sousa sp. & 122581 & 1 & 1139 & 4308 \\
\hline 28 & Pseudorca crassidens & 123081 & 3 & 1211 & 4409 \\
\hline 29 & Feresa attenuata & 123081 & 3 & 1213 & 4415 \\
\hline 30 & Grampus griseus & 123081 & 2 & 1213 & 4415 \\
\hline 31 & Grampus griseus & 123081 & 1 & 1213 & 4416 \\
\hline 32 & Stenella attenuata & 123081 & 1 & 1224 & 4433 \\
\hline 33 & Unidentified Dolphin & 123081 & - & 1228 & 4440 \\
\hline 34 & Unidentified Dolphin & 123181 & - & 1222 & 4502 \\
\hline 35 & Unidentified Dolphin & 123181 & - & 1239 & 4516 \\
\hline 36 & Unidentified Dolphin & 123181 & - & 1259 & 4544 \\
\hline 37 & Unidentified Dolphin & 10182 & - & 1305 & 4606 \\
\hline 38 & Tursiops sp. & 10182 & 1 & 1314 & 4628 \\
\hline 39 & Unidentified Dolphin & 10382 & - & 1319 & 4824 \\
\hline 40 & Delphinus delphis & 10382 & 3 & 1307 & 4901 \\
\hline 41 & Tursiops sp. & 10382 & 2 & 1225 & 5107 \\
\hline
\end{tabular}


TABLE 1 (contd.)

\begin{tabular}{|c|c|c|c|c|c|}
\hline 42 & Tursiops sp. & 10582 & 2 & 1229 & 5111 \\
\hline 43 & Stenella longirostris & 10682 & 2 & 1335 & 5150 \\
\hline 44 & Unidentified Dolphin & 10882 & - & 1559 & 5247 \\
\hline 45 & Grampus griseus & 10882 & 2 & 1605 & 5248 \\
\hline 46 & Unidentified Dolphin & 10882 & - & 1605 & 5248 \\
\hline 47 & Unidentified Dolphin & 10882 & - & 1608 & 5252 \\
\hline 48 & Grampus griseus & 10882 & 2 & 1614 & 5258 \\
\hline 49 & Grampus griseus & 10882 & 2 & 1616 & 5257 \\
\hline 50 & Tursiops sp. & 10982 & 3 & 1642 & 5341 \\
\hline 51 & Stenella longirostris & 10982 & 1 & 1645 & 5411 \\
\hline 52 & Grampus griseus & 10982 & 1 & 1648 & 5426 \\
\hline 53 & Unidentified Dolphin & 10982 & - & 1657 & 5447 \\
\hline 54 & Sousa sp. & 11082 & 1 & 1656 & 5400 \\
\hline 55 & Sousa sp. & 11182 & 1 & 1656 & 5400 \\
\hline 56 & Delphinus delphis & 11382 & 1 & 1658 & 5429 \\
\hline 57 & Stenella longirostris & 11382 & 2 & 1653 & 5412 \\
\hline 58 & Delphinus delphis & 11382 & 3 & 1658 & 5429 \\
\hline 59 & Delphinus delphis & 11482 & 1 & 1718 & 5524 \\
\hline 60 & Deiphinus delphis & 11482 & 1 & 1719 & 5527 \\
\hline 61 & Delphinus delphus & 11482 & 3 & 1719 & 5527 \\
\hline 62 & Delphinus delphis & 11582 & 1 & 1718 & 5528 \\
\hline 63 & Delphinus delphis & 11582 & 1 & 1721 & 5527 \\
\hline 64 & Unidentified Dolphin & 11582 & - & 1720 & 5527 \\
\hline 65 & Unidentified Dolphin & 11782 & - & 1723 & 5542 \\
\hline 66 & Unidentified Dolphin & 11982 & - & 1813 & 5742 \\
\hline 67 & Stenella longirostris & 11982 & 3 & 1849 & 5747 \\
\hline 68 & Feresa attenuata & 12082 & 2 & 1917 & 5811 \\
\hline 69 & Unidentified Dolphin & 12082 & - & 1921 & 5816 \\
\hline 70 & Unidentified Dolphin & 12082 & - & 1946 & 5827 \\
\hline 71 & Ziphius cavirostris & 12382 & 1 & 2215 & 5955 \\
\hline 72 & Grampus griseus & 12482 & 1 & 2315 & 5911 \\
\hline 73 & Tursiops sp. & 12482 & 1 & 2315 & 5910 \\
\hline 74 & Feresa attenuata & 12482 & 3 & 2324 & 5859 \\
\hline 75 & Unidentified Dolphin & 12882 & - & 2247 & 6041 \\
\hline 76 & Tursiops sp. & 12982 & 2 & 2237 & 6247 \\
\hline 77 & Tursiops sp. & 12982 & 2 & 2237 & 6229 \\
\hline 78 & Tursiops sp. & 12982 & 3 & 2234 & 6231 \\
\hline 79 & Unidentified Dolphin & 13082 & - & 2229 & 6246 \\
\hline 80 & Unidentified Dolphin & 20482 & - & 1632 & 6827 \\
\hline 81 & Unidentified Dolphin & 20482 & - & 1620 & 6842 \\
\hline 82 & Stenella coeruleoalba & 20582 & 3 & 1550 & 6912 \\
\hline 83 & Unidentified Dolphin & 20782 & - & 1337 & 7230 \\
\hline 84 & Pseudorca crassidens & 20882 & 3 & 1151 & 7256 \\
\hline 85 & Stenella longirostris & 20982 & 1 & 1053 & 7512 \\
\hline 86 & Grampus griseus & 20982 & 3 & 1041 & 7517 \\
\hline 87 & Unidentified Dolphin & 20982 & - & 1041 & 7517 \\
\hline 88 & Unidentified Dolphin & 20982 & - & 1025 & 7525 \\
\hline 89 & Unidentified Dolphin & 21082 & - & 1025 & 7527 \\
\hline 90 & Pseudorca crassidens & 21082 & 3 & 1025 & 7527 \\
\hline
\end{tabular}


TABLE 1 (contd.)

\begin{tabular}{|c|c|c|c|c|c|}
\hline 91 & Unidentified Dolphin & 21082 & - & 1015 & 7528 \\
\hline 92 & Unidentified Dolphin & 21082 & - & 1023 & 7529 \\
\hline 93 & Stenella longirostris & 21082 & 2 & 1023 & 7530 \\
\hline 94 & Stenella attenuata & 21082 & 1 & 1012 & 7534 \\
\hline 95 & Unidentified Dolphin & 21082 & - & 0822 & 7628 \\
\hline 96 & Unidentified Dolphin & 21082 & - & 0821 & 7630 \\
\hline 97 & Tursiops sp. & 21282 & 3 & 0739 & 7738 \\
\hline 98 & Unidentified Dolphin & 21282 & - & 0729 & 7752 \\
\hline 99 & Unidentified Dolphin & 21282 & - & 0723 & 7759 \\
\hline 100 & Unidentified Dolphin & 21282 & - & 0729 & 7756 \\
\hline 101 & Unidentified Dolphin & 21282 & - & 0720 & 7759 \\
\hline 102 & Stenella attenuata & 21982 & 2 & 0621 & 7940 \\
\hline 103 & Stenella coeruleoalba & 21982 & 1 & 0621 & 7940 \\
\hline 104 & Unidentified Dolphin & 22082 & - & 0547 & 8014 \\
\hline 105 & Unidentified Dolphin & 22082 & - & 0547 & 8014 \\
\hline 106 & Unidentified Dolphin & 22282 & - & 0551 & 8013 \\
\hline 107 & Stenella longirostris & 22282 & 2 & 0547 & 8007 \\
\hline 108 & Unidentified Dolphin & 22282 & - & 0554 & 7954 \\
\hline 109 & Stenella coeruleoalba & 22382 & 1 & 0623 & 7938 \\
\hline 110 & Stenelia coeruleoalba & 22382 & 1 & 0630 & 7938 \\
\hline 111 & Delphinus delphis & 22382 & 1 & 0630 & 7938 \\
\hline 112 & Delphinus delphis & 22482 & 1 & 0742 & 7929 \\
\hline 113 & Unidentified Dolphin & 22582 & - & 0814 & 7934 \\
\hline 114 & Stenella longirostris & 22782 & 1 & 0758 & 7900 \\
\hline 115 & Grampus griseus & 30182 & 1 & 0717 & 7940 \\
\hline 116 & Stenella longirostris & 30182 & 1 & 0732 & 7934 \\
\hline 117 & Stenella longirostris & 30182 & 1 & 0732 & 7937 \\
\hline 118 & Stenella coeruleoalba & 30782 & 1 & 0736 & 7924 \\
\hline 119 & Stenella longirostris & 30782 & 1 & 0734 & 7921 \\
\hline 120 & Stenella coeruleoalba & 30782 & 1 & 0738 & 7922 \\
\hline 121 & Unidentified Dolphin & 30882 & - & 0803 & 7917 \\
\hline 122 & Unidentified Dolphin & 30882 & - & 0800 & 7932 \\
\hline 123 & Unidentified Dolphin & 30982 & - & 0803 & 7933 \\
\hline 124 & Unidentified Dolphin & 30982 & - & 0806 & 7926 \\
\hline 125 & Stenella coeruleoalba & 30982 & 1 & 0806 & 7920 \\
\hline 126 & Grampus griseus & 31082 & 1 & 0804 & 7934 \\
\hline 127 & Grampus griseus & 31182 & 1 & 0817 & 7936 \\
\hline 128 & Unidentified Dolphin & 31182 & - & 0753 & 7936 \\
\hline 129 & Stenella longirostris & 31182 & 3 & 0750 & 7936 \\
\hline 130 & Unidentified Dolphin & 31282 & - & 0716 & 7638 \\
\hline 131 & Tursiops sp. & 31282 & 1 & 0701 & 7947 \\
\hline 132 & Tursiops sp. & 31382 & 1 & 0700 & 7945 \\
\hline 133 & Stenella longirostris & 31382 & 1 & 0659 & 7944 \\
\hline 134 & Stenella longirostris & 31382 & 1 & 0700 & 7941 \\
\hline 135 & Unidentified Dolphin & 31482 & - & 0730 & 7800 \\
\hline 136 & Unidentified Dolphin & 12183 & - & 0839 & 7924 \\
\hline 137 & Tursiops sp. & 12283 & 1 & 0849 & 7838 \\
\hline 138 & Unidentified Dolphin & 12283 & - & 0849 & 7835 \\
\hline 139 & Tursiops sp. & 12483 & 3 & 0740 & 7800 \\
\hline
\end{tabular}


TABLE 1 (contd.)

\begin{tabular}{|c|c|c|c|c|c|}
\hline 140 & Tursiops sp. & 12883 & 1 & 0615 & 7950 \\
\hline 141 & Stenella attenuata & 12883 & 1 & 0607 & 7950 \\
\hline 142 & Tursiops sp. & 12883 & 1 & 0600 & 7953 \\
\hline 143 & Stenella longirostris & 12883 & 1 & 0600 & 7953 \\
\hline 144 & Stenella longirostris & 12983 & 1 & 0552 & 8018 \\
\hline 145 & Tursiops sp. & 12983 & 3 & 0552 & 8020 \\
\hline 146 & Stenella longirostris & 12983 & 1 & 0533 & 8022 \\
\hline 147 & Stenella longirostris & 13083 & 3 & 0616 & 8202 \\
\hline 148 & Tursiops sp. & 13083 & 1 & 0616 & 8207 \\
\hline 149 & Tursiops sp. & 13183 & 1 & 0633 & 8157 \\
\hline 150 & Unidentified Dolphin & 13183 & - & 0644 & 8206 \\
\hline 151 & Unidentified Dolphin & 20183 & - & 0637 & 8205 \\
\hline 152 & Tursiops sp. & 20183 & 2 & 0638 & 8202 \\
\hline 153 & Lagenodelphis hosei & 20283 & 3 & 0626 & 8153 \\
\hline 154 & Unidentified Dolphin & 20283 & - & 0619 & 8148 \\
\hline 155 & Grampus griseus & 20383 & 1 & 0623 & 8149 \\
\hline 156 & Unidentified Dolphin & 20383 & - & 0622 & 8150 \\
\hline 157 & Tursiops sp. & 20583 & 3 & 0700 & 8204 \\
\hline 158 & Pseudorca crassidens & 20683 & 2 & 0738 & 8201 \\
\hline 159 & Grampus griseus & 20683 & 1 & 0754 & 8201 \\
\hline 160 & Feresa attenuata & 20683 & 3 & 0753 & 8154 \\
\hline 161 & Grampus griseus & 21583 & 1 & 0842 & 8123 \\
\hline 162 & Stenella coeruleoalba & 21683 & 1 & 0843 & 8120 \\
\hline 163 & Grampus griseus & 21883 & 1 & 0836 & 8128 \\
\hline 164 & Stenella longirostris & 21983 & 1 & 0835 & 8122 \\
\hline 165 & Stenella longirostris & 30283 & 1 & 0839 & 8119 \\
\hline 166 & Unidentified Dolphin & 30783 & - & 0826 & 8142 \\
\hline 167 & Grampus griseus & 30783 & 1 & 0828 & 8146 \\
\hline 168 & Unidentified Dolphin & 30783 & - & 0833 & 8141 \\
\hline 169 & Stenella longirostris & 30883 & 1 & 0821 & 8151 \\
\hline 170 & Stenella coeruleoalba & 30983 & 1 & 0812 & 8202 \\
\hline 171 & Unidentified Dolphin & 30983 & - & 0807 & 8206 \\
\hline 172 & Stenella attenuata & 31083 & 2 & 0808 & 8208 \\
\hline 173 & Unidentified Dolphin & 31083 & - & 0809 & 8212 \\
\hline 174 & Tursiops sp. & 31183 & 2 & 0829 & 8216 \\
\hline 175 & Unidentified Dolphin & 31183 & - & 0831 & 8208 \\
\hline 176 & Unidentified Dolphin & 31283 & - & 0836 & 8154 \\
\hline 177 & Stenella longirostris & 31283 & 1 & 0834 & 8139 \\
\hline 178 & Stenella attenuata & 31283 & 1 & 0834 & 8139 \\
\hline 179 & Unidentified Dolphin & 31883 & - & 0854 & 8157 \\
\hline 180 & Unidentified Dolphin & 32083 & - & 0753 & 8212 \\
\hline 181 & Unidentified Dolphin & 32083 & - & 0753 & 8221 \\
\hline 182 & Globicephala macorhynchus & 40583 & 1 & 0922 & 8103 \\
\hline 183 & Unidentified Dolphin & 40683 & - & 0954 & 8058 \\
\hline 184 & Stenella longirostris & 40983 & 3 & 0946 & 8058 \\
\hline 185 & Stenella longirostris & 41083 & 1 & 0946 & 8052 \\
\hline 186 & Stenella longirostris & 41083 & 1 & 0946 & 8054 \\
\hline 187 & Unidentified Dolphin & 41083 & - & 0939 & 8059 \\
\hline 188 & Unidentified Dolphin & 41183 & - & 0928 & 8134 \\
\hline
\end{tabular}


TABLE 1 (contd.)

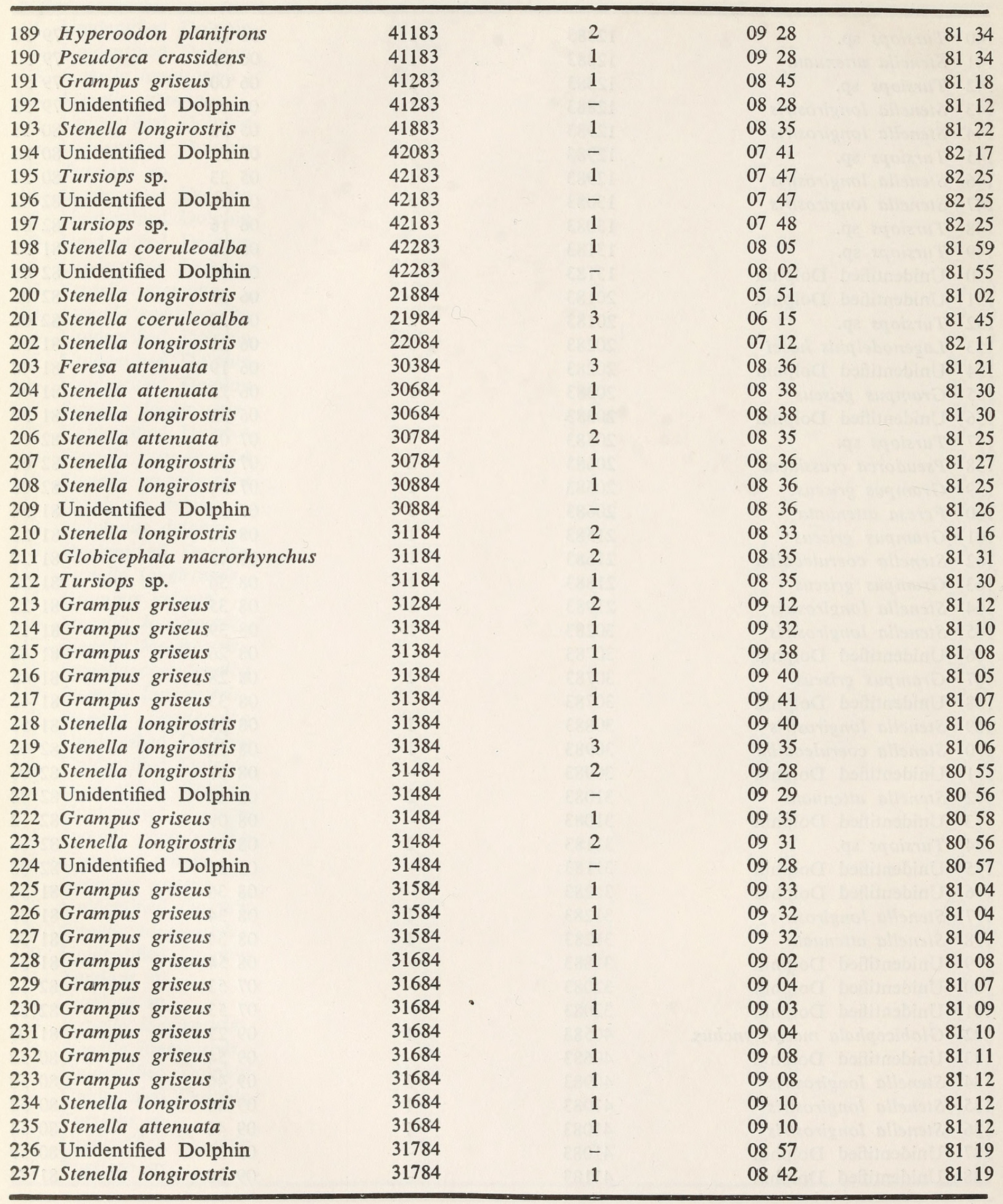


TABLe 1 (contd.)

\begin{tabular}{|c|c|c|c|c|c|}
\hline 238 & Unidentified Dolphin & 31784 & - & 0840 & 81 โ8 \\
\hline 239 & Stenella longirostris & 31784 & 1 & 0838 & 8121 \\
\hline 240 & Grampus griseus & 31784 & 3 & 0836 & 8123 \\
\hline 241 & Stenella longirostris & 31984 & 1 & 0836 & 8122 \\
\hline 242 & Grampus griseus & 32484 & 1 & 0801 & 8159 \\
\hline 243 & Unidentified Dolphin & 32584 & - & 0827 & 8134 \\
\hline 244 & Stenella longirostris & 32584 & 2 & 0835 & 8123 \\
\hline 245 & Stenella coeruleoalba & 32584 & 2 & 0835 & 8123 \\
\hline 246 & Grampus griseus & 32884 & 1 & 0854 & 8116 \\
\hline 247 & Grampus griseus & 32884 & 1 & 0853 & 8115 \\
\hline 248 & Grampus griseus & 32884 & 1 & 0855 & 8115 \\
\hline 249 & Unidentified Dolphin & 33084 & - & 0928 & 8055 \\
\hline 250 & Unidentified Dolphin & 33184 & - & 0925 & 8100 \\
\hline 251 & Stenella longirostris & 40184 & 2 & 0905 & 8106 \\
\hline 252 & Stenella attenuata & 40184 & 1 & 0854 & 8113 \\
\hline 253 & Stenella longirostris & 40884 & 1 & 0927 & 8058 \\
\hline 254 & Stenella attenuata & 40884 & 2 & 0927 & 8058 \\
\hline 255 & Unidentified Dolphin & 40884 & - & 0927 & 8051 \\
\hline 256 & Stenella longirostris & 40884 & 1 & 0928 & 8057 \\
\hline 257 & Stenella attenuata & 40984 & 1 & 0924 & 8059 \\
\hline 258 & Stenella longirostris & 41084 & 1 & 0928 & 8058 \\
\hline 259 & Stenella attenuata & 41084 & 3 & 0933 & 8059 \\
\hline 260 & Tursiops sp. & 41184 & 1 & 0833 & 8116 \\
\hline 261 & Tursiops sp. & 41684 & 1 & .. & . . \\
\hline 262 & Stenella longirostris & 41684 & 3 & . . & . . \\
\hline 263 & Tursiops sp. & 41684 & 1 & $\ldots \ldots$ & $\ldots \ldots$ \\
\hline 264 & Stenella longirostris & 41784 & 1 & $\ddot{0}$ & . \\
\hline 265 & Tursiops sp. & 41784 & 1 & 0835 & 8123 \\
\hline 266 & Stenella longirostris & 41784 & 1 & 0835 & 8122 \\
\hline 267 & Hyperoodon planifrons & 42384 & 3 & 0943 & 8052 \\
\hline 268 & Unidentified Dolphin & 42484 & - & 0933 & 8057 \\
\hline 269 & Unidentified Dolphin & 42484 & - & 0931 & 8056 \\
\hline 270 & Globicephala macrorhynchus & 42584 & 1 & 0910 & 8107 \\
\hline 271 & Stenella attenuata & 42584 & 1 & 0910 & 8107 \\
\hline
\end{tabular}




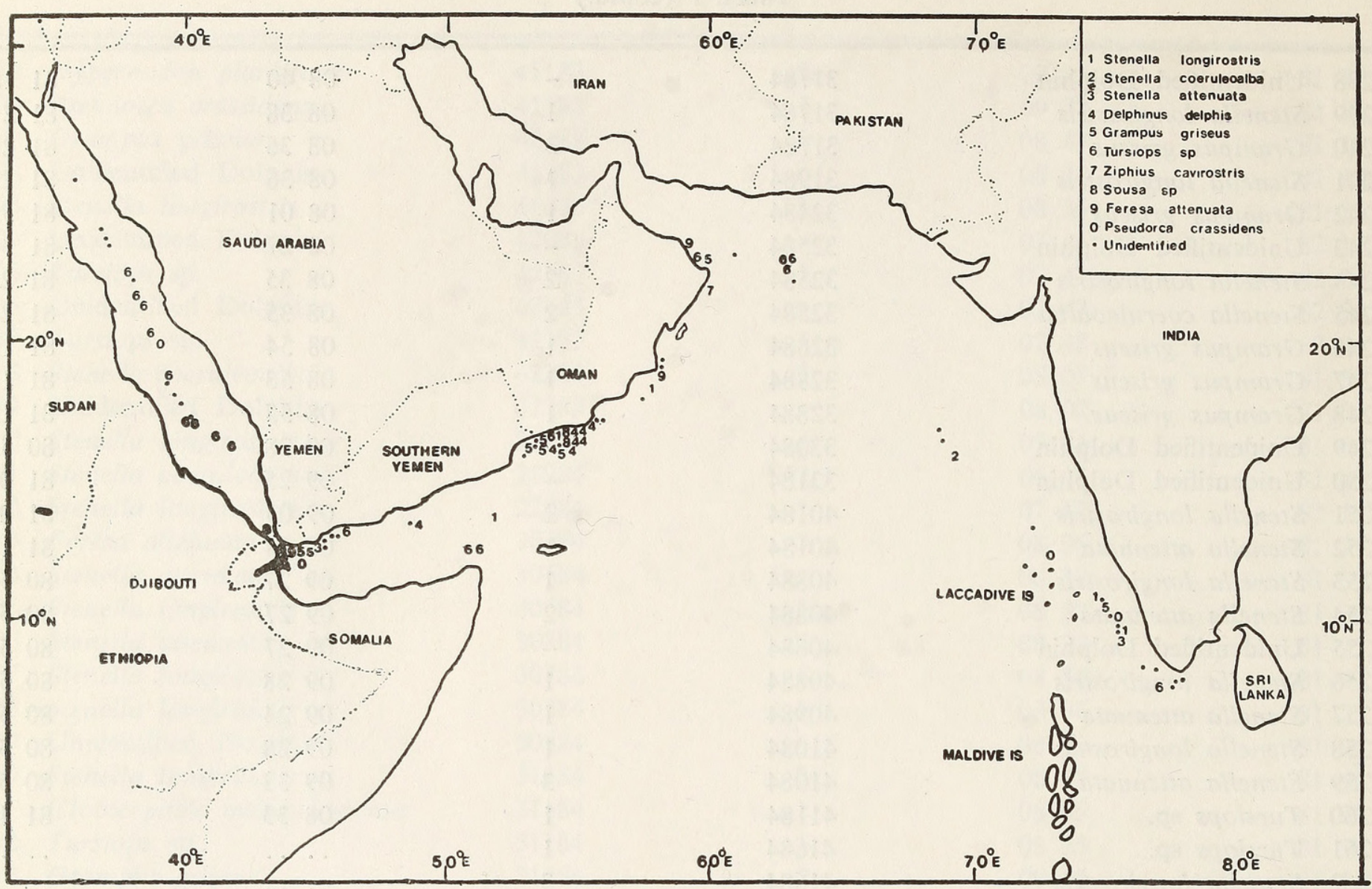

Fig. 2. Sightings of odontocetes in the northern Indian Ocean, 29 November, 1981 through 12 February, 1982.

Each sighting was comprised of a herd. Some herds contained smaller sub-sets called "groups." Groups could be distinguished because animals in them moved in close coordination with one another and were often in clusters, spatially distinct from one another.

Observations of herd or individual behaviour are summarized by species. Informal estimates were made of the number of animals in a herd and their speed of movement. Animals were photographed with $35 \mathrm{~mm}$ Canon cameras and photographs were analysed later to confirm species identity. A flash was used at night to photograph individuals riding-the-bow. Sightings are listed in Table 1 , along with codes indicating confidence in identification $(1=$ posi- tive, 2 = probable, and $3=$ possible identification).

\section{Results AND Discussion}

There were 135 sightings in 1982 (Figs. 2 \& 3), 64 in 1983 (Fig. 4) and 72 in 1984 (Fig. 5). The frequency (number of observations/number of individuals) with which each species was seen is shown in the three year period is listed in Table 2. In six sightings, multi-species herds were involved. As there were no means to assess the degree of interaction between such species or to determine how long they were actually in contact, each species was recorded separately. A total of 3,818 minutes was spent observing animals, but 


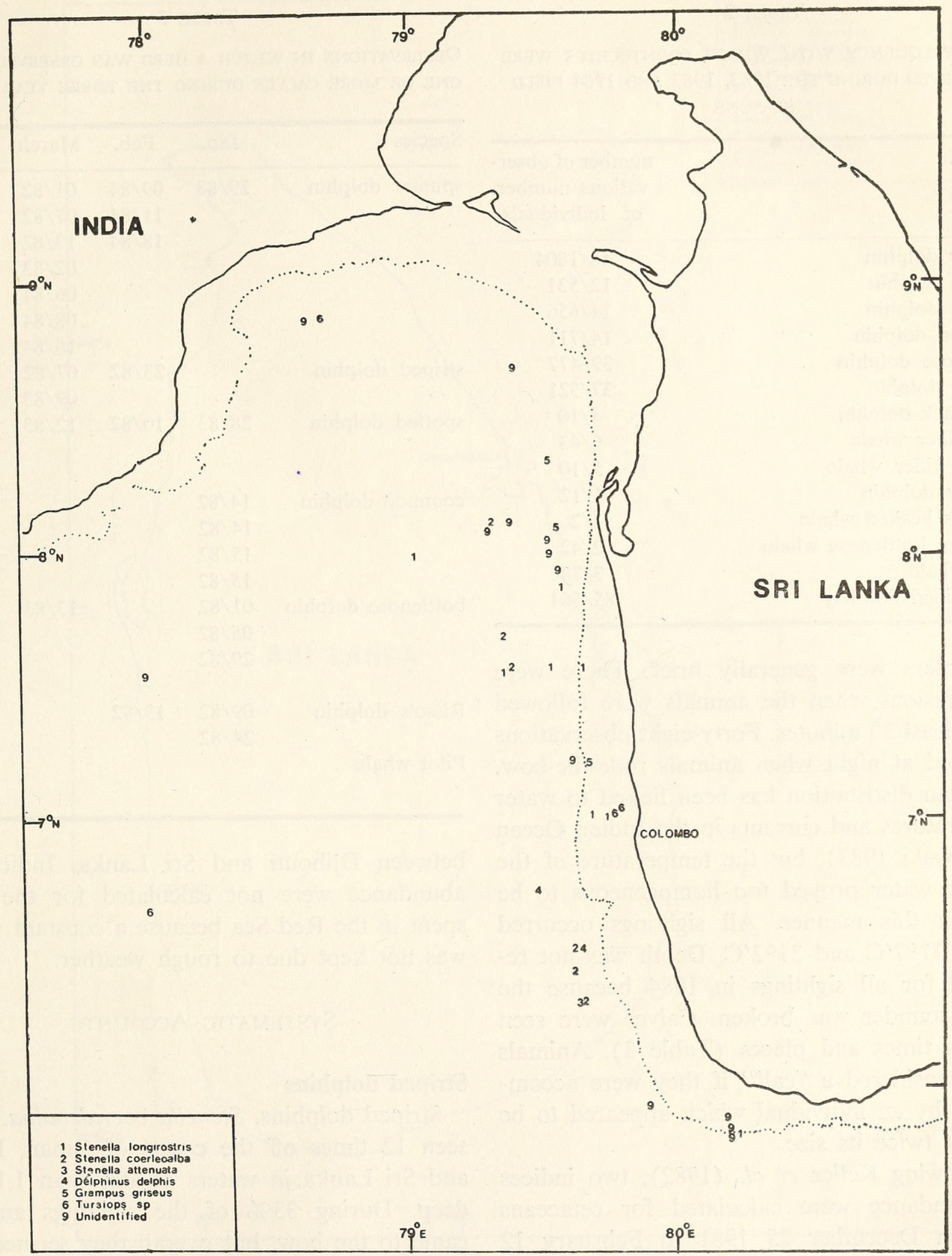

Fig. 3. Sightings of odontocetes off the west and southwest coasts of Sri Lanka, 13 February through 17 March, 1982. The dotted line represents the $1,000 \mathrm{~m}$ depth contour. 
TABLE 2

THE FREQUENCY WITH WHICH ODONTOCETES WERE OBSERVED DURING THE 1982, 1983 AND 1984 FIELD SEASONS

\begin{tabular}{lc}
\hline Species & $\begin{array}{c}\text { number of obser- } \\
\text { vations/number } \\
\text { of individuals }\end{array}$ \\
\hline spinner dolphin & $48 / 1804$ \\
striped dolphin & $12 / 531$ \\
spotted dolphin & $14 / 656$ \\
common dolphin & $14 / 711$ \\
bottlenose dolphin & $39 / 477$ \\
Risso's dolphin & $37 / 321$ \\
humpback dolphin & $4 / 10$ \\
false killer whale & $6 / 43$ \\
pygmy killer whale & $5 / 10$ \\
Fraser's dolphin & $1 / 12$ \\
Cuvier's beaked whale & $1 / 2$ \\
Southern bottlenose whale & $2 / 42$ \\
pilot whale & $3 / 78$ \\
unidentified dolphin & $85 / 664$ \\
\hline
\end{tabular}

encounters were generally brief. There were 33 occasions when the animals were followed for at least 30 minutes. Forty-eight observations occurred at night when animals rode-the-bow. Cetacean distribution has been linked to water temperatures and currents in the Indian Ocean (Nishiwaki 1983), but the temperature of the surface water proved too homogeneous to be used in this manner. All sightings occurred within $21^{\circ} 7^{\prime} \mathrm{C}$ and $31^{\circ} 2^{\prime} \mathrm{C}$. Depth was not recorded for all sightings in 1984 because the depth sounder was broken. Calves were seen various times and places (Table 3). Animals were considered a "calf" if they were accompanied by an individual which appeared to be at least twice its size.

Following Keller et al. (1982), two indices of abundance were calculated for cetaceans seen on December 251981 to February 12 1982 from s/rv Tulip (Table 4). The transects covered an estimated $3,300 \mathrm{~nm}(6,111 \mathrm{~km})$
TABLe 3

OBSERVATIONS IN WHICH A HERD WAS OBSERVED WITH ONE OR MORE CALVES DURING THE THREE YEAR STUDY

\begin{tabular}{lcccc}
\hline Species & Jan. & Feb. & March & April \\
\hline spinner dolphin & $29 / 83$ & $09 / 84$ & $01 / 82$ & $01 / 84$ \\
& & $11 / 84$ & $07 / 82$ & $08 / 84$ \\
& & $18 / 84$ & $13 / 82$ & \\
& & & $02 / 83$ & \\
& & & $06 / 84$ & \\
& & & $16 / 84$ & \\
striped dolphin & & $23 / 82$ & $07 / 82$ & \\
& & & $09 / 83$ & $22 / 83$ \\
spotted dolphin & $28 / 83$ & $10 / 82$ & $12 / 83$ & $01 / 84$ \\
& & & & $06 / 84$ \\
& & & & $16 / 84$ \\
common dolphin & $14 / 82$ & & & \\
& $14 / 82$ & & & \\
& $15 / 82$ & & & \\
bottlenose dolphin & $15 / 82$ & & & \\
& $01 / 82$ & & $13 / 83$ & $21 / 83$ \\
& $05 / 82$ & & & $11 / 84$ \\
& $29 / 82$ & & & $16 / 84$ \\
Risso's dolphin & $09 / 82$ & $15 / 82$ & & $17 / 84$ \\
Pilot whale & $24 / 82$ & & & $11 / 84$ \\
& & & & $25 / 84$ \\
\hline & & & & \\
\hline
\end{tabular}

between Djibouti and Sri Lanka. Indices of abundance were not calculated for the time spent in the Red Sea because a constant watch was not kept due to rough weather.

\section{Systematic Accounts}

\section{Striped dolphins}

Striped dolphins, Stenella coeruleoalba, were seen 12 times off the coasts of Oman, India, and Sri Lanka in waters greater than $1,100 \mathrm{~m}$ deep. During $33 \%$ of the sightings animals came to the bow, but overall they seemed uninterested in our presence. For all sightings, individuals within a herd appeared to be 


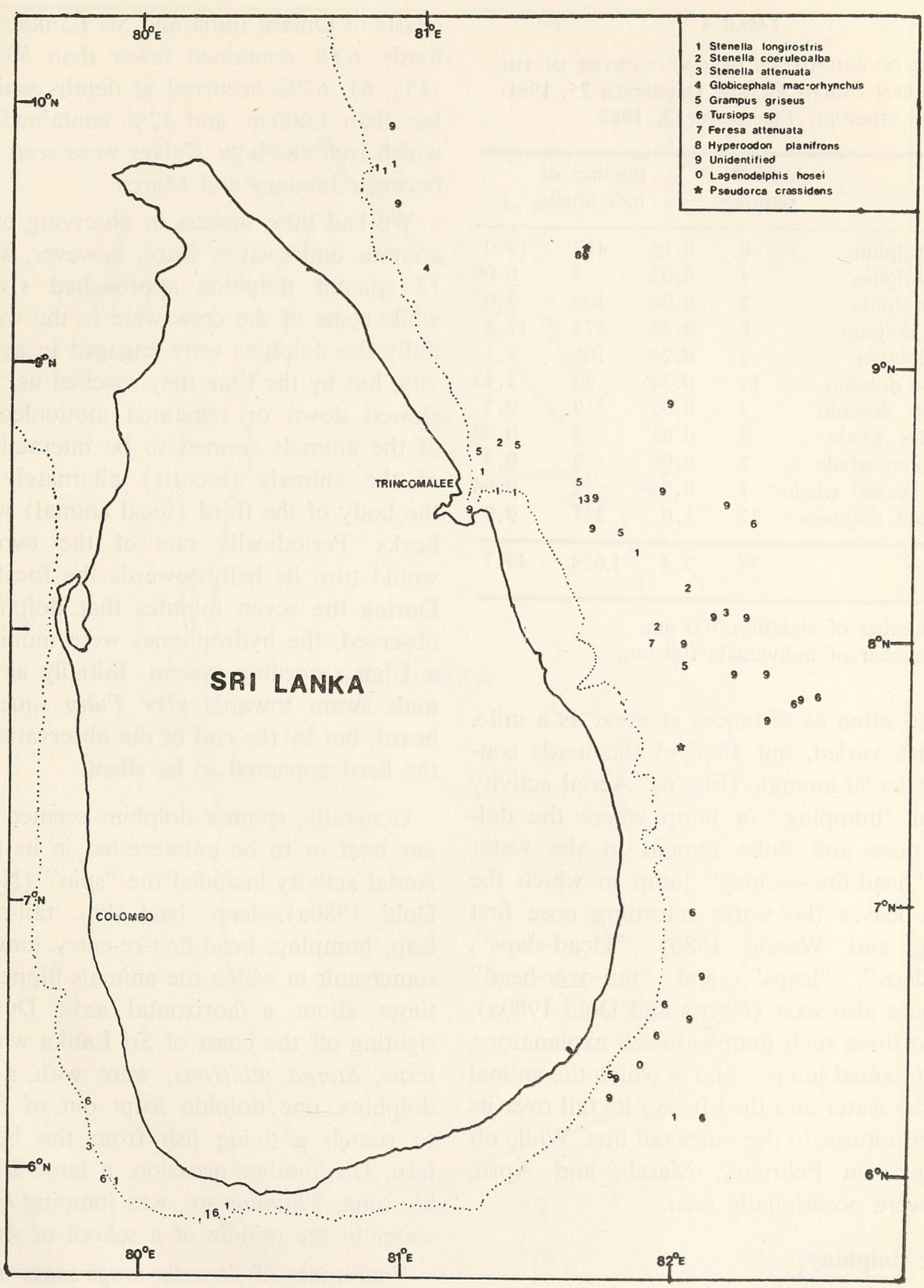

Fig. 4. Sightings of odontocetes off the east and south coasts of Sri Lanka, 20 January through 24 April, 1983. The dotted line represents the $1,000 \mathrm{~m}$ depth contour. 


\section{TABLE 4}

INDICES OF ABUNDANCE OF ODONTOCETES IN THE NORTHERN INDIAN OCEAN, DECEMBER 25, 1981 THROUGH FEBRUARY 12, 1982

\begin{tabular}{lrrrr}
\hline Species & $\begin{array}{c}\text { number of } \\
\text { sightings }\end{array}$ & $\begin{array}{r}\text { number of } \\
\text { individuals }\end{array}$ & $\mathrm{I}_{2}$ \\
\hline spinner dolphin & 6 & 0.18 & 427 & 13.0 \\
striped dolphin & 1 & 0.03 & 3 & 0.09 \\
spotted dolphin & 2 & 0.06 & 100 & 3.0 \\
common dolphin & 8 & 0.24 & 573 & 17.4 \\
Risso's dolphin & 8 & 0.24 & 101 & 3.1 \\
bottlenose dolphin & 11 & 0.34 & 82 & 2.43 \\
humpback dolphin & 3 & 0.09 & 9 & 0.3 \\
false killer whale & 3 & 0.09 & 5 & 0.03 \\
pygmy killer whale & 2 & 0.06 & 9 & 0.3 \\
Cuvier's beaked whale & 1 & 0.03 & 2 & 0.06 \\
unidentified dolphins & 33 & 1.0 & 327 & 9.9 \\
\hline & 78 & 2.4 & 1,638 & 49.7 \\
TOTAL & & & & \\
\end{tabular}

$I_{1}=$ number of sightings $/ 100 \mathrm{~nm}$.

$I_{2}=$ number of individuals $/ 100 \mathrm{~nm}$.

dispersed often as distances as great as a mile. Herd size varied, but $48 \%$ of the herds contained 6 to 50 animals (Fig. 6). Aerial activity included "humping", a jump where the dolphin's nose and fluke remain in the water and a "head-first-reentry" jump in which the dolphin leaves the water returning nose first (Wursig and Wursig 1980). "Head-slaps", "back-slaps", "leaps", and "tail-over-head" leaps were also seen (Norris and Dohl 1980a). The first three such jumps are self explanatory. The last named jump is one in which the animal leaves the water and then brings its tail over its head and returns to the water tail first. While off Sri Lanka in February, March, and April, calves were occasionally seen.

\section{Spinner dolphins}

Forty-eight herds of spinner dolphins, Stenella longirostris, were sighted along the coasts of Oman, India and Sri Lanka. Of these herds, $62 \%$ contained fewer than 50 animals (Fig. 6), 62\% occurred at depths which were less than $1,000 \mathrm{~m}$, and $32 \%$ contained animals which rode-the-bow. Calves were seen 13 times between January and March.

We had little success in observing or filming animals underwater. Once, however, a herd of 15 spinner dolphins approached s/rv Tulip while some of the crew were in the water. Initially the dolphins were engaged in aerial activity, but by the time they reached us, they had slowed down or remained motionless. Three of the animals seemed to be interacting. Two of the animals (escorts) alternately stroked the body of the third (focal animal) with their beaks. Periodically one of the two escorts would turn its belly towards the focal animal. During the seven minutes that dolphins were observed, the hydrophones were monitored on a Uher recording system. Initially as the animals swam towards s/rv Tulip squeals were heard, but by the end of the observation period the herd appeared to be silent.

Generally, spinner dolphins seemed to avoid our boat or to be uninterested in its presence. Aerial activity included the "spin" (Norris and Doh1 1980a), leap, back-slap, tail-over-head leap, humping, head-first-re-entry jump, and a somersault in which the animals flipped several times about a horizontal axis. During one sighting off the coast of Sri Lanka when Little terns, Sterna albifrons, were with a herd of dolphins, one dolphin leapt out of the water to snatch a flying fish from the beak of a tern. On another occasion, a large fish, possibly tuna, Thunnus sp., was jumping out of the water in the middle of a school of spinners.

Four races of Stenella longirostris are found in the Pacific Ocean : 1) Costa-Rican spinner, 2 ) eastern spinner, 3) white-belly spinner, and 


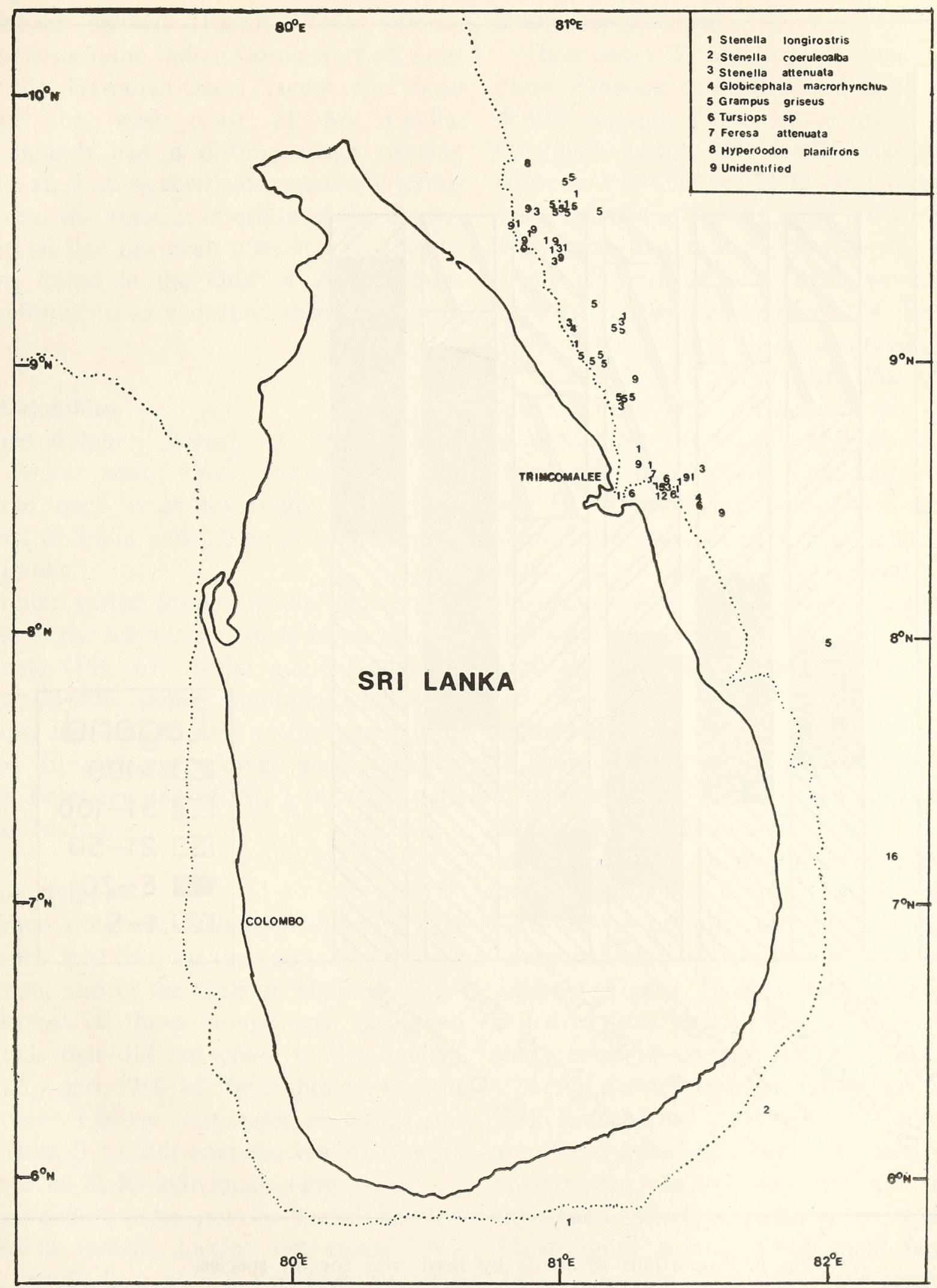

Fig. 5. Sightings of odontocetes off the east coast of Sri Lanka, 22 February through 25 May, 1984. The dotted line represents the $1,000 \mathrm{~m}$ depth contour. 


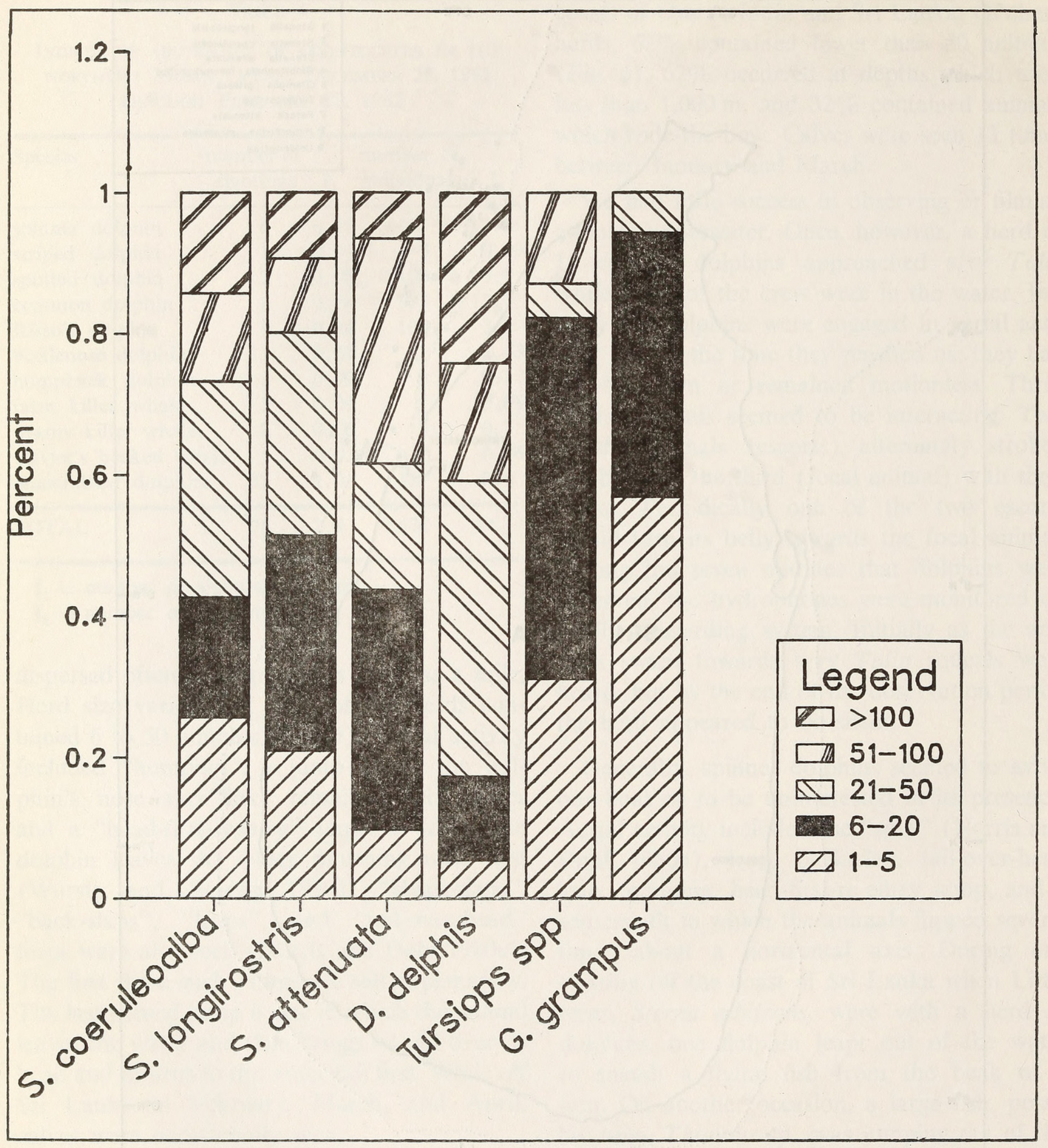

Fig. 6. Proportions of herds by herd, size for all species. 
4) Hawaiian spinner (Perrin 1975). Spinner dolphins seen in the Indian Ocean were all similar to the Hawaiian race, except for those seen of the west coast of Sri Lanka. These animals had a distinct stripe running from the anus along their side, gradually terminating near the anterior insertion of the flipper. This lateral line has been observed on spinner dolphins found in the Gulf of Aden, tentatively referred to as a distinct race (Robineau 1983).

\section{Spotted dolphins}

Spotted dolphins Stenella cf. Stenella attenuata, were seen once during the day off Oman, once while bow-riding at night off the coast of India and 12 times off the coast of Sri Lanka.

Herd size varied from 7 to 200 individuals, but $44 \%$ of the schools contained fewer than 20 individuals (Fig. 6). Aerial activity included head-first-re-entry jumps, humping, head-slaps, and leaps. Individuals came to the bow during $57 \%$ of all sightings. Calves were seen off India in February and off Sri Lanka in January and March.

\section{Common dolphins}

Common dolphins, Delphinus delphis, were seen in the Red Sea, off the coasts of Djibouti and Oman, and in the Gulf of Mannar. Sixtyfour percent of these groups seen contained individuals that did not come to the bow of s/rv Tulip and $57 \%$ of the sightings were at depths over 1,000 m. Estimates of group size varied from 3 to 200 animals, but $42 \%$ were composed of 21-50 individuals (Fig. 6).

Aerial activity was not as varied as that observed in Stenella species, but animals frequently would leap over $2.8 \mathrm{~m}$ high or jump out of the water, landing on their backs. Calves were seen in January.

\section{Bottlenose dolphins}

There were 39 sightings of bottlenose dolphins, Tursiops sp., distributed in all waters at depths varying from 15 to over $1,100 \mathrm{~m}$. Of these herds, $62 \%$ were seen at depths between 100-1,000 m, 51\% were composed of 6-20 animals (Fig. 6), and 64\% contained individuals that rode-the-bow.

On 17 April 1984 at 1415, we followed a herd of bottlenose dolphins for 45 minutes. This herd appeared to be composed of three groups of 10-15 animals each. The groups remained below the surface of the water for approximately two minutes and then surface for about two minutes with continual aerial activity. Head-first-re-entry jumps, back-slaps, headslaps, leaps and tail-slaps were seen. In particular, we noticed that three animals (possibly the same individuals) repeatedly leaped out of the water together in a high circular arc approximately every 25 seconds.

\section{Risso's dolphins}

There were 37 sightings of Risso's dolphins, Grampus griseus, off the coasts of Oman, India, and Sri Lanka. Fifty-three percent of all sightings were made in depths over $1,000 \mathrm{~m}$, but herds were seen at depths as shallow as $100 \mathrm{~m}$. Fifty-seven percent of all sightings were composed of herds containing fewer than five animals (Fig. 6). Herds were sometimes spread out over 1,000 m with groups of 2-15 animals that remained coordinated.

Aerial activity included head-slaps, tail-slaps, and leaps. Like whales, these animals also were seen breaching, fluking when diving, and spy-hopping. In spy-hopping, animals bring their head entirely or partially out of the water. Three times animals spy-hopped facing $s / r v$ Tulip, suggesting that they were curious about our vessel, but they generally did not show interest in our boat. Once while diving with 
them, we saw approximately 50 animals appear about 6-9 $\mathrm{m}$ below us in groups of two or three.

\section{Fraser's dolphins}

Fraser's dolphins, Lagenodelphis hosei, were possibly seen once off the east coast of Sri Lanka in February. The depth was greater than $1,100 \mathrm{~m}$ and they were travelling at approximately 2-4 knots. The group of 12 animals did not seem interested in our boat and animals were only seen humping except for an occasional head-first-reentry jump.

\section{Humpback dolphins}

Humpback dolphins, Sousa sp., were seen four times outside Djibouti Harbor and in Salalah Harbor, Oman. One of the crew (Hal Whitehead) watched three animals herd fish schools into a shallow shoreline in the harbor. Similar behavior has been observed with bottlenose dolphins (Leatherwood 1975, Norris and Dohl 1980b, Hoese 1971).

\section{Medium sized whales}

Two Cuvier's beaked whales, Ziphius cavirostris, were seen off the coast of Oman at a depth of about $850 \mathrm{~m}$. Animals appeared to have white backs with scars on the dorsal surface. Animals did not fluke while diving.

Two unidentified beaked whales were seen off the coast of Oman in waters deeper than $1,000 \mathrm{~m}$. They did not fluke, but backs were arched when diving. From the distance their color appeared black and they averaged about $5.4 \mathrm{~m}$ in overall length.

Hyperoodon planifrons, southern bottlenose whales were tentatively identified off the east coast of Sri Lanka on 11 April 1983 and possibly again on 23 April 1984. In the first sighting, the whales were spread out over approximately $800 \mathrm{~m}$, and 40 animals were arranged in groups of ten while travelling at a speed of 4-7 knots. Estimated lengths were from $5.6 \mathrm{~m}$ to $7.8 \mathrm{~m}$, and animals appeared cream colored, with a pronounced bulbous head. The groups travelled in horizontal formations and no flukes were seen when the animals dove.

Pygmy killer whales, Feresa attenuata were seen once off the coast of Oman and five times off Sri Lanka in waters $120 \mathrm{~m}$ to $1,000 \mathrm{~m}$ deep. All animals sighted were seen in groups of less than six individuals and animals generally travelled slowly, avoiding s/rv Tulip.

False killer whales, Pseudorca crassidens, were seen on six occasions off Oman, India, and Sri Lanka and in the Red Sea in depths greater than $300 \mathrm{~m}$. Animals in the Red Sea rode-the-bow, but during all other sightings, groups seemed to take no interest in our vessel.

- Pilot whales, Globicephala cf. Globicephala macrorhynchus, were seen three times off the east coast of Sri Lanka. On 5 April 1983, members of $\mathrm{s} / \mathrm{v}$ Tulip were in the water with sperm whales when eight pilot whales swam under 12 sperm whales. During the other two sightings, pilot whales were seen in herds of 50 and 20 animals while moving at about two to four knots.

\section{Mixed herds}

Herds containing mixed species were rarely recorded, but it is likely that the crew of $\mathrm{s} / \mathrm{rv}$ Tulip simply did not notice both species when individuals were travelling rapidly in large herds. Different herds of dolphins which were seen in close proximity to one-another occurred more frequently. Risso's dolphins were seen in close proximity to sperm whales, bottlenose dolphins, pygmy killer whales, and false killer whales. Southern bottlenose whales, unidentified dolphins, and false killer whales were seen in the same vicinity on 6 February 1983 and 
pilot whales were seen with sperm whales on 5 April 1983. The extent that herds associate spatially or temporally is not known.

Mixed herds of dolphins included spinner and spotted dolphins, spinner and common dolphins, spinner and striped dolphins, and striped and common dolphins. These sightings are described below:

1. A mixed herd of over 200 spinner dolphins and spotted dolphins was followed for 40 minutes (0815-0855) on 12 March 1983. Spinners were bunched into tight groups, with little aerial activity. The spotted dolphins were organized into looser groups and much aerial activity was seen including leaps, headslaps, head-first-re-entry jumps, and head-overtail leaps. Tuna were seen jumping out of the water among these animals.

2. On 6 March 1984 a mixed herd of about 35 animals were encountered at (0815-0830). There was little aerial activity except for Headfirst-re-entry jumps and occasional tail-slaps and leaps.

3. On 16 March 1984, a group of 75 animals was followed from 1625 to 1705 . Among the entire herd, head-first-re-entry jumps, backslaps, head-slaps, leaps and spins were seen. The spotted dolphins rode the bow, but the spinner dolphins did not. In addition, 175 birds were seen surrounding the school. Species which were identified by one of the crew $(\mathrm{N}$. Davies) included Sterna bergii, Crested terns, Anous stolidus, Brown noddy terns, Sterna anaethetus, Bridled terns, and possibly Sterna bengalensis, Lesser crested terns and Sterna dougallii, Roseate tern.

4. At 1252 on 13 January 1982 , more than 100 common dolphins were seen with spinner dolphins. There was little aerial activity and the herd, which was initially travelling in a long line, seemed to spread out forming small groups.

5. Striped and common dolphins were seen together on 23 February 1982, at 0950. The herd was divided into sub-groups of about six animals spread out over a distance of approximately one mile. The groups travelled at speeds as great as 15 knots.

6. Striped and spinner dolphins were seen in a mixed herd on 25 March 1984 at 1730. All animals were moving at about 10 knots in a horizontal line.

\section{ACK NOWLEDGEMENTS}

I thank Peter Lagendijk, Khamish Al Farsi, Dr. Lex Hiby, Dr. Roger Payne, Cedric Martenstyn, Nihal de Abrew, Elizabeth Kemf, Rosemarie Sommers, and Leslie Joseph for their assistance on s/rv Tulip as visiting scientists. The National Aquatic Resource Agency of Sri Lanka generously helped to facilitate our work in Sri Lanka without their help and encouragement the study would not have been possible. I am most grateful to Stephen Leatherwood, Dr. William Perrin, and Dr. James Mead who analyzed photographs of animals to confirm their identification and Stephen Leatherwood, Dr. Bernd Wursig, Dr. Patricia Moehlman, Dr. Allison Richards, and Dr. John Rhoads for their comments or review of the manuscript. Above all, I thank the Captains, Dr. Hal Whitehead and Jonathan Gordon, and crew of s/rv Tulip, Nic Rotten, Martha Smythe, Margo Rice, Nick Davies, Phil Gilligan, and Vassilli Papastavrou. The study was funded by the World Wildlife FundNetherlands. 
Hoese, H. D. (1971): Dolphin feeding out of water in a salt marsh. J. Mammal. 52(1) : 222-223.

Keller, R., Leatherwood, S. \& Holt, S. (1982): Indian Ocean cetacean survey, Seychelle Islands, April through June 1980. Rep. int. Whal. Commn 32: 503-513.

Leatherwood, S. (1975): Some observations of feeding behaviour of Bottlenosed dolphins, (Tursiops truncatus) in the northern Gulf of Mexico and (Tursiops cf. Tursiops gilli) off southern California, Baja California, and Nayarit, Mexico. Mar. Fish. Rev. 37(9): 10-16.

NishiWAKI, M. (1983): Marine mammal species considered to be in the Indian Ocean. The National Science Museum, Tokyo, Japan. 30pp.

Norris, K. S. \& DoHL, T. P. (1980a): The behavior of the Hawaiian spinner porpoise, (Stenella longirostris). Fish. Bull. 77: 821-847.

(1980b) : The structure and functions of cetacean schools. In: L. M. Herman (ed.) Cetacean Behavior: Mechanisms and Functions, Wiley \& Sons, New York. 211-261 pp.

PERrin, W. F. (1975): Distribution and differentiation of populations of dolphins of the genus Stenella in the Eastern Tropical Pacific. J. Fish. Res. Board Can. 32: 1059-1067.

Robineau, D. (1983) : Note sur le Stenella longirostris (Cetacea, Delphinidae) du golfe d'Aden. Mammalia 47(2): 237-245.

Wursig, B. \& Wursig, M. (1980): Behavior and ecology of the dusky dolphin Lagenorhynchus obscurus, in the south Atlantic. Fish. Bull. 77(4): 871-890. 


\section{$2 \mathrm{BHL}$ Biodiversity Heritage Library}

Alling, Abigail. 1986. "RECORDS OF ODONTOCETES IN THE NORTHERN INDIAN OCEAN 1981-1982 AND OFF THE COAST OF SRI LANKA 1982-1984." The journal of the Bombay Natural History Society 83, 376-394.

View This Item Online: https://www.biodiversitylibrary.org/item/191627

Permalink: https://www.biodiversitylibrary.org/partpdf/157116

\section{Holding Institution}

Smithsonian Libraries

\section{Sponsored by}

Biodiversity Heritage Library

\section{Copyright \& Reuse}

Copyright Status: In Copyright. Digitized with the permission of the rights holder License: http://creativecommons.org/licenses/by-nc/3.0/ Rights: https://www.biodiversitylibrary.org/permissions/

This document was created from content at the Biodiversity Heritage Library, the world's largest open access digital library for biodiversity literature and archives. Visit BHL at https://www.biodiversitylibrary.org. 